BIBLID: 0015-1807, 48 (2021), 1 (pp. 9-24)

UDC 821.111.09:929 Hardi T.

https://doi.org/10.18485/fpregled.2021.48.1.1

\author{
Miriam Sette \\ University of Chieti-Pescara \\ miriam.sette@unich.it
}

\title{
DESIRE, REPULSION AND ACCEPTANCE IN THOMAS HARDY'S FAR FROM THE MADDING CROWD
}

\begin{abstract}
This article explores the Gothic elements in Far From the Madding Crowd and how these elements are mingled with the realistic ones. Such blending of Gothic romanticism with late nineteenth century realism in Hardy's major novels amplifies the thematic and dramatic effects with which the writer was concerned. It is thus apparent that Hardy's fiction contains a great deal of material that originates in Gothic romance, but Hardy's bewildering use of gothic imagery in his non-gothic novel is also very interesting.
\end{abstract}

Keywords: Thomas Hardy, Far from the Madding Crowd, Realism and Romance, folk tale and ballad, pastoral and sensational elements, the dark, melancholy villain-hero.

Abstract: Questo articolo esplora la commistione in Far From the Madding Crowd di elementi gotici e realistici. Tale fusione del genere gotico con il realismo di fine Ottocento amplifica, nei principali romanzi di Thomas Hardy, gli effetti tematici e drammatici. Ė evidente che la narrativa di Thomas Hardy contiene una grande quantità di materiale che ha origine nel romanzo gotico, ma è il ritorno alle antiche forme del romance che giocò un ruolo sottile, se non diretto, nell 'ispirazione artistica di Hardy, allorché compose Far From the Madding Crowd.

Parole chiave: Thomas Hardy, Far From the Madding Crowd, Realismo e Romance, racconto popolare e ballata, elementi pastorali e sensazionali, l'eroe malvagio cupo e malinconico.

For some Romantic authors "beauty was enhanced by exactly those qualities which seem to deny it, by those objects which produce horror; the sadder, the more painful it was, the more intensely they relished it"1. Thomas Hardy was one of the many intellectuals and artists who shared this dark love, this Romantic and Decadent sensibility throughout the whole of the nineteenth century. Like the Romantics, he allowed aspects of his own personality to become aesthetic

${ }^{1}$ Mario Praz, The Romantic Agony, translated by Angus Davidson, London: Oxford University Press, 1970, p. 27. Swinburne's fascination with the femme fatale is shared by Hardy. Elfride, Bathsheba, Eustacia, Felice Charmond, Arabella - even Tess and Sue in some of their traits - deceive, ruin or destroy the unwary male. 
principles. "To find beauty in ugliness is the province of the poet" $(1888)^{2}$, he once asserted. Far From the Madding Crowd (1874) $)^{3}$ already resonates with this feeling and presents, like many of Hardy's narrative masterpieces, his ability to create beauty and poetry out of the bizarre and Gothic elements commonly found in the prose and verse of the Romantic period.

Hardy was strongly influenced by the great Romantics, particularly by the Gothic aspects of their work. The Gothic features of the pathetic fallacy, already evident in Greek or Shakespearean drama long before the concept of 'Gothic' came into being, the use of nature to amplify the effects of terror and the outbursts of natural events to perform further human suffering come to fulfilment in Far From the Madding Crowd. The Gothic elements of the irrationality of events and characters are scattered here and there in a pastoral setting of country realism and tradition (including the superstitions of the Dorset peasants), which Hardy feared would go astray. In this novel we find the first use of the term "Wessex", a name Hardy "had thought to reserve to the horizons and landscapes of a partly real, partly dream-country"4. The contrast of the "partly-real" and the "partly-dream" in that statement reflects how the Gothic works in this novel: as a supportive counterpoise to a human story. The "partly real" aspects - the Weatherbury burial rituals, the divination methods, the gathering in of the crops, the attachment to the land correspond artistically with the "partly dream", irrational, comic, and grotesque aspects - the improbable coincidences, the egotistic villainy, the thwarted burials, and whims of fate. Far From the Madding Crowd encompasses much of the Gothic paraphernalia with its graveyard landscapes, rural superstitions, moments of horror and threatening weather, and yet the novel's power comes from the blend of these elements in a realistic human drama where the likelihood of Bathesheba's character and the power of natural laws direct the rhythm of this narrative. Far From the Madding Crowd is the first example of Hardy's mature aesthetic of a Victorian Gothic mode which leads him to dramatic and yet realistic treatment of the characters, plot, and settings of his other major novels.

The present article explores the Gothic elements in Far From the Madding Crowd and how such elements are mingled with the realistic ones. Such blending of Gothic romanticism with late nineteenth century realism in Hardy's major novels amplifies the thematic and dramatic effects with which he was concerned. It is thus apparent that Hardy's fiction contains a great deal of material that originates in Gothic romance ${ }^{5}$, but Hardy's bewildering use of gothic imagery in his

${ }^{2}$ Florence Emily Hardy, The Life of Thomas Hardy, 1840-1928, London: Macmillan, 1962; reprinted 1965. (This edition combines The Earlv Life and The Later Years. It is generally accredited as Hardy's autobiography), vol. II, p. 213.

${ }^{3}$ Thomas Hardy, Far from the Madding Crowd, ed. Suzanne B. Falck-Yi, Oxford, Oxford University Press, 2002. Subsequent references to this edition are given parenthetically in the text.

${ }^{4}$ Thomas Hardy, Preface to Far from the Madding Crowd, quoted, p. 3.

${ }^{5}$ While his indebtedness to romance can hardly be overestimated, Hardy was also partial to oral forms of literature - folk tale and ballad. We find them mentioned or recorded time and again in the 
non-gothic novel is also very interesting. A primary Gothic aspect to Far From the Madding Crowd includes the intertwining of natural events with human ones. Alterations in Nature's aura often reflect characters' mood switches. Hardy sets up the human drama of Bathsheba's love affairs against the "sinister" atmosphere of a late August night: "The night had a sinister aspect [...] The moon had a lurid metallic look [...] The fields were sallow with the impure light, and al were tinged in monochrome [...] The same evening the sheep trailed homeward head to tail, the behaviour of the rooks had been confused, and the horses had moved with timidity and caution [...] Thunder was imminent" (p. 236). Hardy sketches in minute detail the essence and reality of a forthcoming storm, including the feelings of the animals. A series of small natural events perceived only by Oak, i. e., the "large toad humbly travelling across the path", the "huge brown garden slug [...] com[ing] indoors", as well as the two black spiders, the sheep "all grouped" and frightened by the imminent storm, is "direct message from the Great Mother" (p. 239) and builds up the tension of the scene and of the night. Furtermore, the human events evolve to a climax: Troy refuses to follow Gabriel's warning about an imminent hard rain and overrules Bathsheba's admonition against more drink for the laborers; Bathsheba gets furious and leaves with the women and children. When Gabriel shuts the door on the drunken ravers to protect them from the storm, Hardy accentuates with Gothic hyperbole Nature's terror on the horizon.

A hot breeze, as if breathed from the parted lips of some dragon about to swallow the globe, fanned him from the south, while directly opposite in the north rose a grim mishapen body of cloud, in the very teeth of the wind. So unnaturally did it rise that one could fancy it to be lifted by machinery from below. Meanwhile the faint cloudlets had flown back into the south-east corner of the sky, as if in terror of the large cloud, like a young brood gazed in upon by some monster (p. 242).

The dragon or monster standing for the thundercloud adds Gothic intensity to the scene. Chaos is about to break out. "Rumbles became rattles" (p. 244), and the heifers gallop in terror. Four lightning flashes are followed by the fifth "with the spring of a serpent and the shout of fiend" (p. 245). Thunder comes in with "diabolical" sounds to introduce the "dance of death" (p. 246).

It is this night that Sergeant Troy chooses for the harvest supper dance and for his wedding celebration. Bathsheba and Troy dance to the rhythm of the selected tune "The Soldier's Joy", which requires forty-five minutes of "thunderous footing". The lively dance scene precedes, by chance, Nature's approaching "dance of death" to the nearby county. Oak and Bathsheba share the terror of the night and the three of the lightening as they attempt to save her harvest. They

journals and effectively introduced into the pages of the Wessex novels and stories. See Francesco Marroni and Norman Page (eds.), Thomas Hardy, Pescara, Edizioni Tracce, 1995. 
appear in this frightening atmosphere as two dark forms, two shadows, facing the fierceness of the night:

Heaven opened then, indeed. The flash was almost too novel for its inexpressibly dangerous nature to be at once realized, and they could only comprehend the magnificence of its beauty. It sprang from east, west, north, south, and was a perfect dance of death. The forms of skeletons appeared in the air, shaped with blue fire for bones - dancing, leaping, striding, racing around, and mingling altogether in unparalleled confusion. With these were intertwined undulating snakes of green (p. 246).

Hardy stretches the pathetic fallacy to Gothic extremes and parallels the fervour of the natural events with the fervour of human sensations. Love, life, everything human, seem small and trifling compared to such an infuriated universe and Oak and Bathsheba become transfixed by these natural terrors. Hardy's Gothic sensibility is essential to the drama of the scene. As in traditional Gothic storytelling, Nature plays a theatrical role in the dramatic human action of the tale. Against the realism of nature, Hardy imposes his artistic will, and we get one incident piled on another to increase the reader's excitement. Omens, portents, superstitions and prefigurative symbols are scattered along the text causing uncertainty and doubt. But Hardy employs the supernatural ambiguously: an unnatural or curious incident occurs, and Hardy, like Scott, or Hawthorne, leaves it to the reader to decide whether it is to be explained by natural causes, chance or supernatural mediation.

Suspense and tension, coincidence and deus ex machina intervention are all devices which proved to be attractive to the Victorian serial writers, and which abound in Hardy's Far from the Madding Crowd, as well as in Desperate Remedies, A Laodicean, The Return of the Native, and The Mayor of Casterbridge. Gloomy, mysterious houses, mansions, churches and castles typical of the Gothic romance, with their crumbling furnishings and sinister portraits, provide the theatrical background for many of the novels and tales in the Hardy canon. His architectural interests and training must have impressed upon Hardy the suitability of Gothic architecture with its ready-made power to evoke the heavier emotional moods of awe, pathos, melancholy, terror and horror, as a setting for his fiction of sensation and melodrama. In Far From the Madding Crowd, one of the most Gothic-like representations lies in Hardy's symbolic use of a "gurgoyle" which ruins Troy's final romantic tribute to his dead mistress Fanny Robin:

The tower of Weatherbury Church was a square erection of fourteenth-century date, having two stone gurgoyles on each of the four faces of its parapet. Of these eight carved protuberances only two at this time continued to serve the purpose of their erection - that of spouting the water from the lead roof within [...] It has been sometimes argued that there is no truer criterion of the vitality of any given art-period than the power of the master-spirits of that time in grotesque; and certainly in the 
instance of Gothic art there is no disputing the proposition. Weatherbury tower was a somewhat early instance of the use of an ornamental parapet in parish as distinct from cathedral churches, and the gurgoyles, which are the necessary correlatives of a parapet, were exceptionally prominent -- of the boldest cut that the hand could shape, and of the most original design that a human brain could conceive. There was, so to speak, that symmetry in their distortion which is less the characteristic of British than of Continental grotesques of the period. All the eight were different from each other. A beholder was convinced that nothing on earth could be more hideous than those he saw on the north side until he went round to the south. Of the two on this latter face, only that at the south-eastern corner concerns the story. It was too human to be called like a dragon, too impish to be like a man, too animal to be like a fiend, and not enough like a bird to be called a griffin. This horrible stone entity was fashioned as if covered with a wrinkled hide; it had short, erect ears, eyes starting from their sockets, and its fingers and hands were seizing the corners of its mouth, which they thus seemed to pull open to give free passage to the water it vomited. The lower row of teeth was quite washed away, though the upper still remained. Here and thus, jutting a couple of feet from the wall against which its feet rested as a support, the creature had for four hundred years laughed at the surrounding landscape, voicelessly in dry weather, and in wet with a gurgling and snorting sound (p. 306. My Italics).

The grotesque is described here as a combination of a dragon, a fiend, and a griffin. In other Hardy narratives there are corpses, charnel objects and characters who, although not literally returning from the dead, go along with a broader rule, that nobody in the Wessex novels leaves without coming back again. Far From the Madding Crowd has a graveyard scene, indicating that a sense of affinity with the dead is considered. Hardy memorably depicts a scene where Fanny, and her stillborn baby, lie in all their mortality, quietly disintegrating into earth:

For several years the stream had not spouted so far from the tower as it was doing on this night, and such a contingency had been over-looked. Sometimes this obscure corner received no inhabitant for the space of two or three years, and then it was usually but a pauper, a poacher, or other sinner of undignified sins.

The persistent torrent from the gurgoyle's jaws directed all its vengeance into the grave. The rich, tawny mould was stirred into motion, and boiled like chocolate. The water accumulated and washed deeper down, and the roar of the pool thus formed spread into the night as the head and chief among other noises of the kind created by the deluging rain. The flowers so carefully planted by Fanny's repentant lover began to move and writhe in their bed. The winter-violets turned slowly upside down, and became a mere mat of mud. Soon the snowdrop and other bulbs danced in the boiling mass like ingredients in a cauldron. Plants of the tufted species were loosened, rose to the surface, and floated off (p. 307).

There is no unease here that the dead woman might turn into a demon, preying on the living; but no hint either that she lives on in some transcendent state, in heaven or in hell. An extraordinary feature of this passage is the intermingled 
vocabulary which is both naturalist and supernaturalist: Hardy's delicate treatment of setting and character development keeps the scene from being incredible and Gothic in every respect. An unemphatic, deeply original sense of Hardy's familiarity with the people of the village, the dead as naturally as the living is here disclosed. Nevertheless, picking up this compassionate, companionable tone in speaking of the dead jars with a literary phenomenon of the XVIII century - the craze for the Gothic.

Far From the Madding Crowd is the start of Hardy's mature aesthetic of a Victorian Gothic mode which leads him to dramatic and yet realistic treatment of the characters, plot, and settings of his other major novels. Hardy reconsiders the Gothic not as an isolated fashion but as related to a whole cluster of specialised enquiries into the rituals of death and the ongoing role of the dead in our lives, for an example as the guarantee of our identity and the source of our claim to belong to one soil rather than another. Hardy took the title of his novel from Thomas Gray's poem Elegy Written in a Country Churchyard (1751):

Far From the madding crowd's ignoble strife

Their sober wishes never learn'd to stray;

Along the cool sequester'd vale of life

They kept the noiseless tenor of their way.

Gray's poem is a meditation on the inevitability of death; the vanity of ambition and the universal human desire to be loved. In particular the poem looks at death as a leveller, an indiscriminate force which makes no distinction between the famous on the one hand and the anonymous on the other. The point of the title is surely ironic, as the action of Hardy's novel may be remote from the crowd, but it is also violent and far from noiseless. Nevertheless, the grave remains central to Hardy's novel too. When Fanny Robin dies, Sergeant Troy shows his devotion to her, which runs far deeper than his love for Bathsheba, by a lavish expenditure on a marble tombstone for her grave. His impetuous tending of the grave borders on the obsessive and yet it lacks any sense of practical planning. The grave is badly damaged by heavy rain when water spews from the mouth of a gargoyle on the church roof and cascades onto the site where Fanny lies buried. Hardy shows us in this novel the tragic implications of foolish human behaviour and also the whims of fate and nature that affect human beings so painfully. When Troy observes the damage caused by the beast's jaws, he becomes agitated, as if, Hardy tells us, "his intention had been known and circumvented" (p. 309). In spite of that, we keep the illusion of reality of a mishap set against Troy's impotence. It is Gabriel Oak who makes the necessary repairs and thus ensures the grave survives. Troy loses the perception of himself as a hero of sorts, feels unhappy and runs away from Weatherbury. Something plausible or mysterious holds back Troy from actualizing happiness. Every single action of Troy toward 
Fanny Robin has been doomed and he is eventually reunited with Fanny (at least in Bathsheba's generous imagination since, in Hardy's mind, Fanny is already a disintegrating corpse) when, after his own death, he is interred by her side.

The late Enlightenment, particularly when Gray's Elegy was published, is a period of intense and highly specialised learned activity. Death is as significant as life. Eighteenth-century graveyard talks are often conducted by religious teachers of any creed. But they can be at the same time a key issue for natural science, comparative religion and anthropology. In eighteenth-century views, death can be a physical process that a frontier science might push back, as well as a mystery to which dogmas and rites adhere, and the richest focus for popular superstition ${ }^{6}$. Similarly, in Victorian England (an age of positivistic rationalism) areas unaffected by science and even adverse to it are still present. From these two opposite trends emerges a conflict which can be easily identified in the literature of the time. Hardy's fiction, although engaged in a vital and ongoing dialogue with science, is concerned with the difficulty of ensuring any kind of objective analysis in an unavoidably subjective, perspectival world - a world in which everything is always in flux.

Science features in Far From the Madding Crowd in Gabriel Oak's intervention to protect Bathsheba's ricks from fire and storm, and in his using his knowledge to save her sheep. However, Oak acts with the biblical teaching that man was given the responsibility of exercising dominion over nature. In this and many other such cases, questions of which, and to what degree, religious or scientific indications might have affected what Hardy wrote cannot be resolved with any certainty. "The very ground-thought of Science", Hardy copied into his notebook, "is to treat man as part of the natural order"7. But Hardy is ambivalent here as it is typically the case in intellectual circles of the Victorian society. The Victorian world meant rationalism and intellectual will to research combined with experimentation, but what must be stressed here is that there was a constant and wide undercurrent of transgression and morbidity which partly found its literary expression in the sensationalist interpretative mode of the new genre. Such a transgression led to the discovery of new themes strongly dependent on a context rapidly changing and conscious of the consequences that the doctrine of material values, at the basis of the capitalistic system, would lead to. Moreover, since the figure of the scientist could only momentarily establish a sense of order and values in a world where the human psyche was recognized to be essentially

${ }^{6}$ There were different ways in which the later Enlightenment studied death: the earliest of these folklore studies was Henry Bourne's Antiquitates Vulgares; or, the Antiquities of the Common People (1725). Bourne's self-confessed remit was to record rather than suppress the practises he encountered among his flocks. The fascinating two-volume almanac of British superstitions and customs by John Brand (1744-1806): Observations on Popular Antiquities (1777) was a heavily revised and annotated version of Henry Bourne's Antiquitates vulgares.

${ }^{7}$ Lennart A. Björk, ed., The Literary Notebooks of Thomas Hardy, 2 vols, London, Macmillan, 1985, vol. I, p. 65. 
precarious, it is thus no wonder, at this historical moment, to register a surprising compatibility of scientific reason and fascination for the irrational.

Gothic texts and Far From the Madding Crowd share thus a fascination for the forms that evil can take. The emergence of psychoanalysis at the end of the nineteenth century was already foreshadowed in the Gothic's own images of perversion, transgression and the forbidden, all of which are dramatized in Hardy's Far From the Madding Crowd. Nevertheless, Gothic literature's elemental and straightforward presentation of good VS evil is made more complex by Hardy who, like many Victorians, especially those with an interest in science, didn't think in terms of 'good' vs 'evil', but (like George Eliot) in terms of 'mixed' human beings. Hardy moves back and forth between realism (if we broadly define that as the portrayal of mixed human beings in a recognisable time and place, acting in a plot in which events are plausibly connected even if they are also out of the ordinary), sensationalism and the Gothic. The effect of the novel is to remind us that we are subject to a great many forces over which we have only limited control - these forces may be divided into those which are external (storms, etc.) and those which are internal (e.g., obsession, such as Boldwood's) - but also that we do have this limited control, and can train ourselves to develop it (this seems to be Oak's role in the novel). Unlike the realistic fiction for which Hardy is best known, Far From the Madding Crowd is the first representation of Hardy's successful Victorian Gothic.

In the light of its rich symbolism, it is right to notice how Far From the Madding Crowd combines elements of biblical allegory, romance, and mystery so as to capture the reader's interest. Still, it is the way in which the story is related, rather than its symbolic content, that makes Far From the Madding Crowd linger in the reader's imagination. Part of this attraction derives from Hardy's blurring of the boundaries which undermines stable relationships, disrupts conventions of order and negates straightforward categorization. By employing Gothic traditions and tropes, he creates a sort of heterotopic ${ }^{8}$ space which modulates between the familiar and the unfamiliar and challenges the vision's role in producing empirical and reliable knowledge. Moreover, it allows the writer to raise questions about reality, identity's uncertainties and complexities.

Tracing our way through Troy's wanderings, we come to see how the narrator creates his own rhetoric out of a traditional set of moral oppositions between Self and Otherness. He portrays an attractive character (Francis Troy) whose vices - especially drinking and gambling - come to the fore in order to lay bare the darker side of human nature. Hardy shows his ability to investigate human nature by adopting the Gothic genre and its elusive ideological and structural framework. In Far From the Madding Crowd, Hardy needs no supernatural

${ }^{8}$ For an explanation of the enigmatic term "heterotopia", see Michel Foucault, The Order of Things (1966), London, Routledge, 2005. 
monsters, for in Troy (as well as in Aeneas Manston and Alec d'Urberville), he has introduced some sort of villain who resembles a version (albeit diminished) of the dark, melancholy villain-hero of the Gothic novelists and their followers and is himself a brute capable of horrific torment/indifference at the expense of the persecuted maidens Fanny Robin and Bathsheba.

In Far From the Madding Crowd, it is the character of Troy who allows Hardy to investigate humanity's innate dual nature. Troy is the other in Weatherbury rural community of farmers. As soon as he enters the scene, he is depicted as an exceptional case, given his possible aristocratic birth, and his seductive sex appeal. Bathsheba, as if bewitched, immediately capitulates to Troy's advances. Troy is thus the character that destabilises the order in the little community where the story takes place and the one who sets the plot in motion. Although Troy might well resemble the very familiar type of Victorian seducer, presumably Hardy had in mind, for this character, the dark, melancholy villain-heroes of the Gothic novelists (and their followers). The potential symbolic and poetic force of the Gothic romance and its underlying eroticism was certainly recognized by Hardy ${ }^{9}$.

Francis Troy, Gabriel's natural enemy, is responsible for deferring Bathsheba and Oak's union. Although Bathsheba deems Oak a faithful and reliable friend, she is fatally attracted to Troy for his good looks and his strong sexual drive. Yet Bathsheba does not surrender to Troy to arouse Gabriel's jealousy, but because, at the beginning of the novel, she is an inexperienced and unguided young woman. Differences of this kind are related to the changes Hardy made in the characterisations of the two protagonists. Bathsheba is an independent woman, but with some flaws, most notably vanity and stubbornness. The former is exemplified in the episode at the beginning of the novel when Gabriel observes her admiring herself in a looking-glass. Her insistence on marrying Troy and her reluctance in admitting to be wrong on several occasions are clear signs of her obstinacy. In the course of the novel both traits - vanity and stubbornness - are softened by circumstances, so there is an evolution in her personality ${ }^{10}$. Gabriel stands out for his wisdom and practical knowledge, as exemplified by his ability to determine the time at night from the position of the stars. While Oak inspires respect in the young and inexperienced Bathsheba, Troy relies on the fascination exerted by his uniform and role. He is perfectly aware of that and, consequently, he appears self-confident. Moreover, he conceives love as a battlefield. The sword scene among the ferns has Bathsheba subdued and conquered by the sergeant fighting

${ }^{9}$ This may be seen in Chapter LII of Tess of the d'Urbervilles, where Tess is startled to find Alec stretched out on a slab in Kingsbere Church. It is a powerfully evocative scene which implies that Alec will achieve his longed for sexual death with Tess, as well as a literal death which he does not foresee.

${ }^{10}$ So the narrator and Oak assume, but as Phillip Mallett and others have argued, that reading of the mirror scene is a male view, and not one wholly supported by the text. The narrator offers and then disowns it; Gabriel asserts it, but only when his own vanity is hurt by Bathsheba's indifference towards him. See Phillip Mallett, "Our first glimpse of Bathsheba" in Far From the Madding Crowd, London: Connell Guides, 2018, pp. 10-13. 
as if he were at war. During the second encounter between the two in the hayfields, Troy uses again his best weapon, that is to say flattery, and its effect on Bathsheba is significantly defined as "capitulation" by the narrator (p. 171). It is not surprising, therefore, that Francis Troy succeeds in convincing Bathsheba to marry him. Bathsheba, on the other hand, must suffer the consequences of her hasty decision, with Troy's dark nature coming to the fore.

But Hardy's skill in analysing morbid states of mind is especially remarkable in the third part of the novel, where Troy's regressive tendencies take over. A rich and respectable married man (his wife is a tenant-farmer - reasonably well off), after his former fiancée's and his (illegitimate) child's death, he leaves his wife taking a trip that soon turns into an emotional pilgrimage toward the source of obsessions and of passions pent up for years: "Troy wandered along towards the south [...] A composite feeling, made up of disgust with the, to him, humdrum tediousness of a farmer's life, gloomy images of her who lay in the churchyard, remorse, and a general awareness to his wife's society impelled him to seek a home in any place on earth save Weatherbury. The sad accessories of Fanny's end confronted him as vivid pictures which threatened to be indelible, and made life in Bathsheba's house intolerable" (p. 313). Troy is only too happy to indulge in the mood of the moment, whether it's love or contempt or self-pity. This climax evaporates into a blend of the gruesome and the weird as Troy, delirious after having visited Fanny's grave, has visions of the haunting landscape:

At three in the afternoon he found himself at the foot of a slope more than a mile in length, which ran to the ridge of a range of hills lying parallel with the shore, and formed a monotonous barrier between the basin of cultivated country inland and the wilder scenery of the coast. Up the hill stretched a road nearly straight and perfectly white, the two sides approaching each other in a gradual taper till they met the sky at the top about two miles off. Throughout the length of this narrow and irksome inclined plane not a sign of life was visible on this garish afternoon. Troy toiled up the road with a languor and depression greater than any he had experienced for many a day and year before. The air was warm and muggy, and the top seemed to recede as he approached.

At last he reached the summit, and a wide and novel prospect burst upon him [...] Nothing moved in sky, land, or sea, except a frill of milkwhite foam along the nearer angles of the shore, shreds of which licked the contiguous stones like tongues.

He descended and came to a small basin of sea enclosed by the cliffs. Troy's nature freshened within him; he thought he would rest and bathe here before going farther. He undressed and plunged in. Inside the cove the water was uninteresting to a swimmer, being smooth as a pond, and to get a little of the ocean swell, Troy presently swam between the two projecting spurs of rock which formed the pillars of Hercules to this miniature Mediterranean. Unfortunately for Troy a current unknown to him existed outside, which, unimportant to craft of any burden, was awkward for a swimmer who might be taken in it unawares. Troy found himself carried to the left and then round in a swoop out to sea. 
He now recollected the place and its sinister character. Many bathers had there prayed for a dry death from time to time, and, like Gonzalo also, had been unanswered; and Troy began to deem it possible that he might be added to their number (pp. 313-314).

Although the road is long and tedious and the reference to a "miniature Mediterranean" is comic/mock-heroic, Troy's concluding vision is of an ancient burial place which clearly recalls the grave where Fanny's corpse lies. Fanny, the woman he had sacrificed to his compulsive love for Bathsheba, is another victim of masculine pride and passion. She is seduced and deserted. It is arguable that, in Far From the Madding Crowd, besides dealing with feelings of guilt in general, Hardy does no more than a dozen other novelists had done in conceiving a character, namely Troy, who is a wicked seducer. Troy's recognition of the wrongs for which he is responsible as both a husband and a father is not enough, however, to absolve or redeem him. Troy's perverse humanity ${ }^{11}$ is ostensibly shown up in his using his power as employer to coerce others into doing what he tells them to do - which turns out to mean that he makes them get drunk, not that he modifies their beliefs. Although in Far From the Madding Crowd Troy succeeds in imposing his codes of belief and action on Weatherbury natives, however he takes charge of the farm only to risk ruining it. Bathsheba and Oak are the ones who bring it under control. In a rejected passage, Troy tries corrupt and illegal practices to increase the farm's income confirming thus that he is unable to bring his surroundings under his rational and practical control as a conqueror. He is just a wicked lonely exile.

In Chapter XXIII, Francis Troy, a military man who regards himself as appointed to command and to be obeyed, bullies his workforce into getting drunk and runs away from responsibility, in part out of boredom, He runs away from a failed marriage, and a wife who knows he has been unfaithful. When he gets bored and runs out of money, he comes back. Surely this makes him rather a trivial figure, who depends on his wife's money and has no constancy of purpose - something less than a Gothic villain. By virtue of his rashness, Troy is estranged from a whole way of life that, by marrying Bathsheba, he had taken for granted, When he returns he still assumes his rights over Bathsheba (and her money and property, and therefore over her workforce).

This appalling novel has in store for Troy, as well as for Fanny, neither relief nor release. Fanny's journey (like Hetty's in Eliot's Adam Bede) leads her to no wisdom or insight. From her punitive humiliation and protracted torment, she

${ }^{11}$ R. Kearney Strangers, Gods, and Monsters: Interpreting Otherness, London and New York, 2003. According to Kearney: "[Monsters] are lurking within us here at home - often in the depths of our selves [...] Some monsters need to be welcomed, others struggled with. The important thing $[\ldots]$ is to try to tell the difference" (pp. 61-62). This seems to be the hermeneutical task chosen by Hardy for the character of Troy. 
reaps at the end of the novel only more intolerable pain and death. This is true of Troy's journey too: he turns out to be below the level of moral insight. Even Manston, or Alec d'Urberville, learn something: Troy learns nothing. In line with the emerging 1890s pessimism, no recognition of the wrongs for which he is responsible as a military man, a husband and a father; no absolution and redemption is conceded him. Troy's folly is the greed for independence that separates him from Bathsheba, places him on the road and leads him to isolation. Like Troy's derangement, Boldwood's suicide dislocates him from the culture that has shaped his beliefs and values. However, whereas Boldwood's narrative describes the arc of agony and oblivion, Troy's agonies last only for a day or so and he shows no insight. Troy is all too obviously unchanged when he returns - no wiser, and no kinder. For this reason, it is Boldwood that is the more interesting, and more nearly tragic figure of the two.

The trauma of dislocation and degradation is not limited to Troy and Boldwood. Also Oak traces his withdrawal from grace and his embarkation on a slow, painful journey into the the world around him. Thomas Hardy takes care to insist that Oak is less interested in himself than in the world around him, therefore Oak is an ideal choice of wise character standing aloof, given the extraordinary nature of his experiences. Oak's traversal through the Wessex world is grounded within a solid reality but is a pilgrim's progress with no view of the Celestial City from the top of the Delectable Mountains ${ }^{12}$.

By multiplying Troy's fate in this way, by replicating its trajectory into the fates of Boldwood, Oak and, to a certain extent, of Fanny Robin, Hardy makes it clear that the novel has a higher target in its sights than the three characters. There is no reference in the text to the Immanent Will, beyond what one may loosely call a Greek sense that human beings are not wholly in control of their own lives. This insidiousness of everyday reality is brilliantly rendered in the plot and the uncanny is seen to reside beneath the fragile surface of a deceptively reassuring social order. Hardy explores the problem of destructive energies released unconsciously in Far From the Madding Crowd. Also the organic community of Weatherbury is characterized by competition and struggle, namely forces of nature, often beyond the control of individuals. Troy cannot battle his debauch-

12 "Then I saw in my dreams, that on the morrow he got up to go forwards, but they desired him to stay till the next day also; and then said they, we will (if the day be clear) shew you the delectable mountains, which they said, would yet further add to his comfort, because they were nearer the desired heaven, than the place where at present he was. So he consented and stayed. When the morning was up, they had him to the top of the house, and bid him look south, so he did: and behold at a great distance he saw a most pleasant mountainous country, beautified with woods, vine-yards, fruits of all sorts; flowers also, with springs and fountains, very delectable to behold. The he asked the name of the country; they said it was Immanuel's land: and it is as common, said they, as this hill is, to and for all the pilgrims. And when thou comest there, from thence, said they, thou mayest see to the gate of the Celestial City". J. Bunyan, The Pilgrim's Progress: From this World, to That Which Is to Come, ed. R. Pooley, London, 2008, pp. 58-59. 
ery; Boldwood and Oak cannot resist Bathsheba's appeal; Bathsheba lays down her arms before Troy's allure. They all are powerless to control their own nature and sharing the common needs, vulnerability and mortality, refute the rationale that divides people into dominant and bad, like Troy, and compassionate and good, like Oak. Unlike Gothic writers, with the villains and wronged heroines, etc., Hardy - like many other Victorian novelists - deals with mixed or complex human characters. In the language used by the novelists themselves (notably Thackeray, distinguishing himself from Dickens), he is nearer the traditions of realism than those of idealism (i.e., he avoids characters of an ideal or unmixed beauty or badness). Notwithstanding this, Hardy's tastes and interests indicate an affinity with some of the Romantics and nineteenth-century decadents. This may not explain the kind of fiction that Hardy wrote, but it does suggest something about his imagination and the kind of subject matter he would naturally use in his fiction. In Far From the Madding Crowd a modern view of life and a dreamy one, that has little to do with realistic representation of the actual world, are allowed to coexist rather than succeed each other.

If we look at the novel afresh from this perspective, we are forced to wrestle with contradictions and ambiguities that complicate our response to it. The loss of faith that overcame him as a young man eroded this assumption, but the emotional side of Hardy could not easily be reconciled to what his intellect ascertained to be the truth. This ambivalence gives rise to the characteristic tension in his work between reason and emotion, between the real and the unreal, between man-made codes of behaviour and the more natural physical urges of human beings. Doubtlessly interested in the irrational side of human experience, Hardy appropriates a psychological approach, through the elements of textual hybridity. And it is precisely this peculiarity of the text, combining conflicting material, textual, and historical signs, that reveals Hardy's intent to draw attention to the outbreak of an uncontrollable untamed identity in order to disrupt those systems of classification through which cultures organize experience in favour of a more complex definition of the boundaries. Oak and Boldwood strive in vain to defend the borders of the little community of Weatherbury from the outer, metaphorical and factual, incursions of Troy, the outcast ${ }^{13}$.

${ }^{13}$ Julia Kristeva, in a Biblical context, points out that abomination could be accomplished either by breaching a law of worship, or by violating a precise and closed symbolic order. According to Kristeva, religious rituals are attempts to establish boundaries around the abject, protecting the Symbolic from the pollution or chaos embodied by the abject. In her analysis, rituals maintain and repair broken or threatened barriers between the sacred, safe, clean world of the symbolic, and the polluted, unclean territory of the abject. Troy's alienation from the life of the little community of Weatherbury may thus be interpreted with reference to Julia Kristeva's psychoanalytic theory of abjection. From this methodological perspective, Troy's humanity, neither subject, nor object, especially in the final phase of his life, is articulated as abject, namely ab human. The literal meaning of "abject" is "cast away". According to Kristeva, the abject is rejected and distanced from the self to form the subject. Because the abject is both part of the self and of the other, the subject forever pursues and abhors 
However well founded such views may be, the full scope of the novel remains beyond their reach. The plot of Far From the Madding Crowd emphasizes Nature's cruel impartiality. Good and bad perish alike, regardless of merit. And Boldwood's and Fanny Robin's stories, for example, reveal that there is nothing natural about the idea of justice, which is rather the invention of human culture. The tragedy of mankind, rather than in understandable human conflicts of interest, lies in the inhuman imperatives of natural laws, whose ultimate rationale is denied by Hardy. This is an idea he derived from Herbert Spencer in particular: behind every known, there stands a further unknown. Accepting that implication is to recognize the extent of humanity's subjection to mysterious forces of nature which are indifferent to its fate, and over which humans have limited control. This is surely what we are invited to learn from Oak, who can't control the storm, but can ameliorate its effects (and put out the fire, save the sheep, and help Bathsheba find a degree of happiness). Although there is something pitiless about the way the reader's expectations are played with all over the text of Far From the Madding Crowd, some relief is attained only at the perplexing end of the story ${ }^{14}$.

In spite of the effect of lightness deriving from the observation of the harmonious natural landscape of a serene Weatherbury, what impresses the reader's imagination in a striking way is a sense of darkness which implicitly affirms the impossibility to interpret the text according to a harmonious hermeneutical design. The memory of Bathsheba's smile: "Then Oak laughed, and Bathsheba smiled (for she never laughed readily now), and their friends turned to go" (p. 389) resonates in the mind of the reader long after the last speech of the novel has faded. The real darkness is what exists and remains in the heart of men, and by extension, in the heart of the reader. It is not a moral or evil darkness; it is an immense and pervasive gloom that engulfs the puny human spirit. It is simply a matter of course!

By placing the social drama of Troy, Boldwood, Fanny Robin, Bathsheba and Oak in the wider, natural perspective of an ultimately inscrutable universe, Hardy discloses the flimsiness of the views humans take of life, but does not discount them as worthless. The effect of the last sentence of the novel: "But since "tis as 'tis, why, it might have been worse, and I feel my thanks accordingly" (p. 389) is to disengage us from the characters' plight and pull us back to a point where we can judge it not only with empathy, but also with profound detachment. The world in Far From the Madding Crowd is less than we want it to be, but it is still something. This last sentence is seriously intended by Hardy and persuades the reader not to sum up the final vision of the novel, in misanthropic despair at the futility of human existence. Universe is without meaning; but we can make it

\footnotetext{
the abject. J. Kristeva, Powers of Horror: An Essay on Abjection, New York, Columbia University Press, 1982, pp. 1-17.

${ }^{14}$ Phillip Mallett suggests a similar conclusion in Noticing Things: Hardy and the Nature of 'Nature', in The Achievement of Thomas Hardy, London, Palgrave, 2000, pp. 155-170.
} 
better rather than worse. Thus, what the story of Bathsheba succeeds in doing is to present the inescapable condition of man, an insignificant speck in relation to universe, but surely not passive: Fanny's grave can be repaired; Oak can recover from disaster; the sheep, the ricks, etc., are saved along the way; Bathsheba can smile. The idea that human life is nonsense in the great scheme of things, is counterbalanced in Chapter II of the novel where we read that: "[Oak] returned to the hut, bringing in his arms a new-born lamb, consisting of four legs large enough for a full-grown sheep, united by a seemingly inconsiderable membrane about half the substance of the legs collectively, which constituted the animal's entire body just at present. The little speck of life he placed on a wisp of hay before the small stove, where a can of milk was simmering" (p. 17). This passage is counter to views on the idea of Nature in Hardy, which over-emphasises the negatives. It can be argued that even if human life is just a speck, it is creative, and not just passive. Life (human, or that of a lamb or a calf) is a "speck", but nonetheless that speck, at any rate in its human form, has consciousness. Oak's conduct is congruent with Thomas Henry Huxley's argument in Man's Place in Nature (1863) that it is mankind's ethical responsibility to control a morally indifferent environment. In this resigned spirit of the protagonists of the story sounds an inner calm, conscious of the fact that the real 'horror' would be to question the 'whys' and 'wherefores' of this inscrutable situation. In the end man and nature are at peace because the sentient creature (Bathsheba) recognizes the 'going with the tide' is the only way to survive. She welcomes the darkness knowing that eventually it will be dispelled by light through a cycle of eternal recurrence. Thus, Bathsheba imparts to the reader an ultimate lesson of human wisdom.

\section{REFERENCES}

Bunyan, John, The Pilgrim's Progress: From this World, to That Which Is to Come (ed. Roger Pooley), London, Penguin, 2008.

Foucault, Michel, The Order of Things (1966), London, Routledge, 2005.

Huxley, Thomas Henry, Evidence as to Man's Place in Nature, Cambridge, Cambridge University Press, 2009.

Kearney, Richard, Strangers, Gods, and Monsters: Interpreting Otherness, London and New York, Routledge, 2003.

Kristeva, Julia, Powers of Horror: An Essay on Abjection, New York, Columbia University Press, 1982.

Kutzbach, Konstanze; Mueller, Monika (eds), The Abject of Desire: The Aestheticization of the Unaesthetic in Contemporary Literature and Culture, New York, Rodopi, 2007.

Mallett, Phillip, ed., Far From the Madding Crowd, London, Connell Guides, 2018. 
Mallett, Phillip, ed., The Achievement of Thomas Hardy, London, Palgrave, 2000.

Marroni, Francesco and Norman Page (eds.), Thomas Hardy, Pescara, Edizioni Tracce, 1995.

Praz, Mario, The Romantic Agony, Translated by Angus Davidson, London, Oxford University Press, 1970.

Punter, David, The Literature of Terror: Vol. 1: The Gothic Tradition, 2 vols, 2nd ed., London, Longman 1996.

Миријам Сете

\author{
ЖЕљА, ОДБОЈНОСТ И ПРИХВАТАЮЕ У ДЕЛУ ТОМАСА ХАРДИЈА \\ FAR FROM THE MADDING CROWD \\ (Резиме)
}

Томас Харди познавао је неке од готских писаца, као и њихове следбенике. По свој прилици је читао Ен Редклиф и Метју Грегори Луиса. Извесно је да је познавао романтичарске обраде готског жанра, попут Франкештајна Мери Шели, али и сензационалистичке романе Вилкија Колинса. Више је него извесно да је своју склоност ка готском Харди развио преко балада, романтичарске поезије (у првом реду Лорда Бајрона), као и дела Шекспира, Бањана, Скота, Ејнсворта и Диме оца, које је читао у детињству. Обнова готског („неоготски”, како је прозван касније) био је израз романтизма. Био је смео, драматичан, уско везан за природу, а призивао је мрачну меланхолију и средњовековне мистерије. Намера је била да наговести утиске и ум подстакне на асоцијације које би призвале идеализовану слику средњег века каква jе предочена у легендама и витешким романима. У питању је истински повратак на корене романских књижевности, уз поновно откриће емоционалне уметничке интуиције, историје и језика, изван илуминистичког рационализма неисторичног интелекта (nonhistorical). У Енглеској је повратак на ове древне форме одиграо танану улогу, мада не директну, на уметничку инспирацију Томаса Хардија када је састављао своје дело Far From the Madding Crowd.

Кључне речи: Томас Харди, реализам и романса, народна прича и балада, пасторални и сензационални елементи, мрачни и меланхолични антијунак.

Примљено 9. маја 2021, прихваћено за објављивање 29. јина 2021. године. 